\title{
Motives that Drive Students to Use the School Library in the Taipei Municipal Mingchuan Elementary School: A field study
}

\author{
Kun-Yu Lai \\ Librarian \\ Mingchuan Elementary School \\ Taiwan, ROC
}

\begin{abstract}
In the past twenty years, most studies of elementary school libraries were about how the library was used. However, little research regarding why students would like to visit the library and what are their favourites in the library has been carried out. The purpose of this study is thus to understand the motives and impact factors of graders library use at school library. This study adopted the qualitative research in a semi-structured in-depth interview and a participant observation research. The interviewed objects are sixteen 3 6 graders who borrowed books or media frequently from the school library. The studies showed being curious, feeling bored, desiring to be recognized, seeking topics of their own interests, getting respect, finding fulfilment, enjoying leisure-time, getting better scores, getting virtual rewards, pleasing parents, and peer competition are eleven main motives that drive students to use the school library. There are some impact factors can affect the library use including library factor and non-library factors such as: the abundance and attractiveness of collections; the independence and distance of premises, the comforts of interior space; the equipments including network, light, air-conditioner, and audio-video facilities; the competence and friendly support of the librarian, the reading activities, and longer opening hour. Moreover, the schoolwork, the significant others, spiritual space, etc. are also important. The analyses found that the function of the school library lies not only on reading, circulating and searching, but also being a place for leisure and social activities. That is a successful school library is not only a library, but also a living room at home. Ideally, the school should enhance the positive linkage between the students and the library as well as the librarian should be a facilitator to connect them. On the other hand, the librarian should encourage students read enthusiastically by making library as a warm, convenient, and comfortable environment. As a result, the student would like to be a long-term patron of the library.
\end{abstract}

\section{Introduction}

In the past twenty years, most studies of elementary school libraries were about how the library was used. However, little research regarding why the students would like to visit the library and what are their favorites in the library has been carried out. The purpose of this study is thus to understand the motives and impact factors of graders library use at school library. 


\section{Related Literature}

Wiegand (2003) argues that the failure to include analysis of "library as place" or "reading" question in its research agenda prevents the LIS community from adequately understanding the social and cultural preconditions that frame the library's present. And Wiegand suggests that it might be more illuminating to focus on "the library in the life of the user" than "the user in the life of the library".

This study falls within the paradigm of naturalistic inquiry. McKechnie(1996) summarized that the naturalistic paradigm provided a way to explore the research questions about which little is now known, through the eyes of the children themselves, and in a manner which resulted in overall views with rich, thick descriptions of the processes involved.

Guthrie; Wigfield; Humenick; Perencevich; Taboada; Barbosa. (2006) identified seven major instructional practices that increase motivation for reading and reading comprehension. Those include: (1) using content goals; (2) affording students choices of the text they read; (3) properties of texts; (4) social goals; (5) teacher involvement; (6) extrinsic rewards and praise; (7) emphasizing mastery goals.

Clee; Maguire (1993) found that the total environment has the greatest effect about the use of library. The children's comments suggested that they would like to see some changes or additions.

\section{Research Methods}

This study adopted the qualitative research to understand why the students would like to visit the school library. Three methods were used: (1) in-depth interviews with individual patrons; (2) participant observation; (3) document analysis such as librarian's notes. The interviewed objects are sixteen $3 \sim 6$ graders who borrowed books or media frequently from the school library. All graders, visiting the library, were observed.

Each interviewee, 7 boys and 9 girls, was recruited with a box of chocolates. The date of interviewing was conducted for four months from April to July 2006. The date of participant observation was conducted more than one year from January 2006 to February 2007. And 124 days in library were recorded.

\section{Findings}

According to the records of in-depth interviews, with the aid of participants' observation, there are eleven major motives, including intrinsic or extrinsic, have been identified. The intrinsic motives are being curious, feeling bored, desiring to be recognized, seeking topics of their own interests, getting respect, finding fulfillment and enjoying leisuretime. The extrinsic motives are getting better scores, pleasing parents, getting virtual rewards and peer competition. 


\section{Intrinsic motives}

\section{Being curious}

Children studying in the elementary school are full of curiosity. Being curious thus has become the strongest intrinsic desire that drives them to visit the school library. According to the observation, they are not only interested in books themselves but also in the process of lending and returning books. Interestingly, students affiliated to different grades show interests in diverse kinds of books. For example, most junior graders are interested in drawing books whilst senior graders are interested in books related to novels and relationship. Because they can find books of their own interests, rather than from those assigned by teachers, they feel that the library is more attractive than courses. Therefore, in many occasions it is difficult for students, especially for the 1 st ad 2 nd year students, to leave the library when the course bell starts ringing.

\section{Feeling bored}

"Feeling bored" is one of the most significant characteristics of children after school, especially for those grown up in a big city like Taipei. This is mainly because the majority of their parents spend a lot of time in the office so that children are lack of accompany after they go back home. The school library thus becomes a place for them to kill time. According to my contacts, 4 out of the 16 children visited the library just because they wanted to spend the time after the lecturing hours. They did not have a particular target in the library.

\section{Desiring to be recognized}

According to the Maslow theory, people need to love and to be loved. School children are of course not exception. One of the most straightforward ways that students feel to be loved in the school is to be recognized or to be admired. Unfortunately, most of them feel frustrated by frequent low scores of examinations. In the Mingchuan Elementary School, surprisingly, a lot of students love to visit the library simply because they feel to be recognized - they quite often get admiration because of sharing with the librarian and being involved in the regular library affairs such as tidying up the bookshelves, moving books, and sorting books etc.

\section{Seeking topics of their own interests}

Most parents would like to select books for children regardless of whether those books are interesting to children. Accordingly, children feel themselves are deprived of the right to select their own books. The school library, on the other hand, becomes "compensation" to children because they can explore their own interests there. In addition to reasons mentioned above, students love to visit the library simply because they have the freedom to explore what they want in such a space full of every kinds of knowledge.

\section{Getting respect}

"Knowledge is power" is true for scientists also true for school children. According to my observation, children would like to compete what they know apart from the knowledge in the textbooks. The school library thus becomes a "database of treasure" 
for children to get extraordinary knowledge. They quite often show terminologies of a special filed to their classmates, and most strikingly - the more they show the more respect they obtain. This is one of the main reasons that drive them to visit the library.

\section{Finding fulfillment}

The students get the achievement by challenging the quantity of reading. With the use of internet, students can get various kinds of gratification. The school library is such a place where they can get a sense of accomplishment for the computers linked to the internet. Compared with getting the contentment from books, or even from school teachers, seeking to answer the question via search engines such as Yahoo is indeed more satisfied. The research showed that students feel enormous sense of achievement just because of the responses from the internet, no matter whether the answers are correct or copying from somewhere.

\section{Enjoying leisure-time}

Compared with the classroom, the school library is a place almost free of pressure to children. They do not feel disciplined within the library, although they are asked to be quiet. Besides, a lot of collections in the library are children magazines, comics and novels, all of which are leisure-oriented and thus children feel fun to read these materials. Nowadays the computers in the library are installed with some game software and they have become a big attraction to students in the school library. Of course the programs for computer games should be selected by the school teachers or the librarian to make sure no violence and pornography is accompanied.

\section{Extrinsic motives}

When investigating extrinsic motives attracting children to visit the library, the researcher found that they were quite different from the intrinsic motives shown above. Interestingly, they appear more relationship-related. The top four items among all investigated extrinsic motives are: getting better scores, pleasing parents, getting virtual rewards and peer competition. Details for each item are described as follows:

\section{Getting better scores}

The motivation of using library has close connection with the grade of the students. Some students go to the library by reading extracurricular book to get more lexical knowledge for enhancing composition ability and obtain higher score. Some use internet to accomplish the assignment like Nature science reports or scientific exhibitions or hand in the homework by internet. As a consequence, library utility and student assignment have positive connection.

\section{Pleasing parents}

As mentioned in previous paragraphs, the school library has become a place for children to seek information of their own interests. Nevertheless, most parents still regard the school library is purely for studying. They feel secure that their kids are staying at the library even though parents do have ideas of what children are doing. According to my 
observation, some students came to the library sometimes just for pleasing their parents. They may not really study or write assignments hard. Nevertheless, I still appreciate these kids because of their mind of obedience.

\section{Getting virtual rewards}

In the Mingchuan Elementary School, every tutor and the librarian would like to encourage their students to visit the school library as often as they can. Some of them awarded students (according to their visiting frequencies) with visible prizes such as book gift coupons, school ground-party point coupons, or ice cream etc. Not surprisingly, most students were deeply encouraged and were very enthusiastic with reading for the prizes.

\section{Peer competition}

Some students would like to take to show how many books they borrow from the library, and regard the leading numbers as a "victory". Hence this kind of behavior has become a competition among children with similar ages. Interestingly, the research shows that it has turned out to be a strong driving force for some students to visit the school library.

During the research on the motives, the researcher also found some impact factors that influence the student's library use at school library. The impact factors can be categorized into to library factors and non-library factors.

\section{Library factors}

\section{Collections}

The abundance of collections. The abundant collections are an important factor to inspire students to visit library. The attractiveness of library comes from the content of the books, the writing skill, the continuous tension on the series books and the interested new books. The call number means nothing to the students, whereas the drawing or pictures on the cover page are much meaningful. Just as the halo effect, the students think a series of books have the same attractiveness, while he/she read one of them. Some of students appreciate the writing skill of the author, and then seeking for the other works of the author. Some students always browse the collections for the new issue. Anyhow, the books appealing to the students attract the graders to rush into the library desirably.

The arrangement of collections. The arrangement of collections also influences the students to use library. Some of the hot and new issues have been exhibited upwards on the desk, or put the front cover of drawing books obverse on the shelves for the convenience of the students who are in a hurry. It is also convenient for the students who were not specially designated for specific books to check out in fleeting ten minutes. Convenience makes the students willing to return into library for browsing and standing in a queue.

\section{Premises and facilities}


The factors that influence the student's library use including the location of the premises; the distance between the premises and the classrooms; the comforts of interior space; the facilities of computer network well-appointed; and as a place where the students could see a movie.

Location of the premises. A good location of the premises means that the site is independent and convenient. It is the best location for the graders that the library site is far away from the executive office that the potential stress makes the graders feel not relaxed, free and easy.

The distance between the premises and the classrooms. The distance between the site and the classroom influences the will of the graders visiting the library. The longer it is, the lower the grader's will is to the library.

The comforts of interior space. The comfortable feeling comes with a warm atmosphere in the interior space of the library. Students would like the library with arranged and decorated space, light music, and quiet. The library in the Mingchuan Elementary School valued the users more than the books, that the users can follow their inclinations and have not burdened stress in quiet space. Thus the library embodied the subjectivity of the user, rather than the collections.

Students would like to seat themselves on the wooden reading area. Two interviewees mentioned they like the library because the feeling of "my own sky" when they lay down. The research showed the interior space must concern the feeling of users. Light, music, air conditioning, decoration, and reading environment are all important.

The facilities of computer network well-appointed. The main purpose of most graders accessing to the library is for searching, getting E-mail, and online game. Though there is notice to say "first priority for data searching", the students still use computer to play games by the name of "data searching".

As a place where the students could see a movie. Another factor that the students like to access the library is that the students may see a movie out of class despite ten minutes. It is not important whether the film is continuous for the students.

\section{Librarian, activities, and regulations}

What factors that influence the student library use includes librarians, activities, and regulations, as well as collections, premises and facilities.

Librarian. The librarian is an interface between the library and students. Thus the students will feel esteemed and willing to visit the library while the librarian serves with friendly attitude and supporting words. Librarian does not only circulate mechanically, but also interact with eyes contacting, calling his/her name, praising, and encouraging them. Then the librarian and students weave an invisible networking gradually, shaping a place full of feeling of humanness. And that is why the library is always overcrowded. The students take the librarian as a teacher. So the words and behavior of librarian affect the students' attitude toward the library use. 
Activities. Another factor that influences grader's library use is the promotion of reading. Clearly, there were a large number of graders accessing into the library to lend books for the reason of incentives, such as ice cream, books token, etc. Although it is controversial, the students usually long for the reading activities, since there existing fun, rewards, honor, and the feeling of "difference from others".

Regulations. Longer opening hour makes the students feel convenient. Since anyone may access the library freely before the librarian comes off duty at 5 P.M. It's very important for the students that they can access into the library at any moment, and find any service person such as the librarian or volunteer, even though the manpower is not enough. Thus the students pleased to attend to the library.

\section{Non-library factors}

Beside the library factors, there are non-library factors including schoolwork, significant others, spiritual space, and others.

\section{Schoolwork}

The schoolwork is an important factor of the core of life. And heavy homework and arts supplementary will reduce the use of library. Just like one mother said: ...far away, and heavy homework, examining everyday, tests at least three disciplines everyday, mathematics, Chinese, and society. So they have no time to read other books from the library.

\section{Significant others}

The significant others who affect the use of library are classmates, teachers, librarian and parents. Classmates influence each other's reading by inviting, recommending, following fashion. It will become popular to lend books from library, while most students like it.

The instructors such as teacher and librarian are significant for students' reading. The more the teacher emphasis reading, the more often students of class visit the library to lend books. The more the librarian listens to the students, the more often the students access the library.

The parents play an important role for the graders who think their parents as a role model. Home regulation is another factor. If they read books instead of watch TV at home, they will like to use library more.

\section{Spiritual space}

The library is a live organization which affords students a lively space for reading alone, sharing, discussing, reading together, or interacting with others. Library as place for the students to frame "my own sky" to mend the crack of heart while sorrowing. The student found his refuge in books, so he/she used the library as the place where transferring mood, coming in for a chat, relaxing in spirit.

\section{Others}


Besides, there are some accidental factors affecting student to access library. For example, there would be fewer students to visit library while examination week is coming or school will hold an athletic meet. Furthermore, while raining, more students were assembled at school library since they can't use the playground. Under some condition, library seems to be the alternative choice.

\section{Conclusion}

In conclusion, the analyses found that the function of the school library lies not only on reading, circulating or searching, but also being a place for leisure and social activities. That is a successful school library is not only a library, but also a living room at home. For the ideal purpose, we suggest that the school should enhance the positive linkage between the students and the library as well as the librarian should be a facilitator to connect them. On the other hand, the librarian should encourage the students read enthusiastically by making library as a warm, convenient, and comfortable environment. As a result, the students would like to be a long-term patron of the library.

\section{References}

Clee, J; Maguire, R.(1993). Library environment and library usage. Library Management. 14 (5), 6-8.

McKechnie, Lynne. (1996). Opening the Preschoolers' Door to Learning: An Ethnographic Study of the Use of Public libraries by Preschool Girls. Ph. D. Dissertation.

Guthrie, John T.; Wigfield, Allan; Humenick, Nicole M.; Perencevich, Kathleen C.; Taboada, Ana; Barbosa, Pedro.(2006). Influences of Stimulating Tasks on Reading Motivation and Comprehension. Journal of Educational Research, 99(4), 232-245.

Wiegand, Wayne A.(2003). To reposition a research agenda: what American studies can teach the LIS community about the library in the life of the user. Library Quarterly, 73(4), 369-382.

\section{Author Note:}

Kun-Yu Lai, the librarian in Taipei Municipal Mingchuan Elementary School. He is also a student, studying in the Graduate School of Library Information Science in National Taiwan University. After being a sales engineer in private company, working at knowledge bank of library in a foundation, and being the chief of MIS in architecture association, he has served as librarian at elementary school more than five years. His major interest lies in running a comfortable library environment and promoting children's reading that contribute to student learning.

\section{Acknowledgement:}

I would like to express my sincere appreciation to my advisor Dr. Shan-Ju Lin Chang for her advice, guidance, and encouragement throughout the course of my research. This paper is a part of my thesis, supported spiritually by Guo-Ben Hung, the principal of Taipei Municipal Mingchuan Elementary School. Thanks for Dr. Chun-che Chang, Dr. Shu-Wen Han, and Hsiang-Mu Guei helping correct my English drafts. A very special thanks to Prof. Shiow-jyu Lu for her kindness and reminder. 